Selcuk Journal of Agriculture and Food Sciences

http://sjafs.selcuk.edu.tr/sjafs/index

Research Article
SJAFS

(2020) 34 (1), 14-18

e-ISSN: 2458-8377

DOI:10.15316/SJAFS.2020.189

\title{
Effect of Enzyme Addition to Diets Containing Different Levels of Alfalfa Meal on Performance and Egg Quality Parameters of Laying Hens
}

\author{
Elias Khudhur Najm Najm ${ }^{1}$, Yusuf Cufadar ${ }^{1, *}$ \\ ${ }^{1}$ Selcuk University, Faculty of Agriculture, Department of Animal Science, Konya, Turkey
}

\begin{tabular}{l}
\hline ARTICLE INFO \\
\hline Article history: \\
Received date: 23.09 .2019 \\
Accepted date: 11.12 .2019 \\
\hline Edited by: \\
İbrahim AYTEKİ; Selçuk University, \\
Turkey \\
Reviewed by: \\
Erinç GÜMÜŞ; Aksaray University, \\
Turkey \\
Ünal KILIÇ; Ondokuz Mayıs University, \\
Turkey \\
\hline
\end{tabular}

Keywords:

Alfalfa meal

Performance

Eggshell quality

Egg yolk color

Laying hens

\begin{abstract}
This study was conducted to investigate the effect of enzyme addition to diets containing different levels of alfalfa meal on performance, egg quality and egg yolk color in laying hens. Twenty-four weeks-old, 144 Lohmann-LSL laying hens were allocated to 8 experimental groups. The experiment, 4 different levels of alfalfa meal $(0,4,8$ and $12 \%)$ and 2 different levels $(0$ and 1000 $\mathrm{mg} / \mathrm{kg}$ ) enzyme containing 8 different experimental diets were carried out with 6 replications according to $4 \times 2$ factorial design.

The results of study indicated that there were no differences in egg production, feed intake, feed conversion ratio, egg weight, egg mass and eggshell breaking strength among the treatment groups $(\mathrm{P}>0.05)$. The eggshell thickness had no significantly affected by the dietary alfalfa meal levels and interaction groups, but eggshell thickness was significantly higher in group fed with containing enzyme than the group of without enzyme $(\mathrm{P}<0.01)$. In the egg yolk color parameters, the $\mathrm{L}^{*}$ value was significantly affected by dietary alfalfa meal levels $(\mathrm{P}<0.01)$, and the groups fed with alfalfa meal containing diets at 8 and $12 \%$ levels were significantly lower than the others $(0$ and $4 \%)$. The $a^{*}$ and roche values were significantly and similarly affected by the interactions $(\mathrm{P}<0.05)$, and the groups fed with alfalfa meal (with or without enzyme) diets at 8 and $12 \%$ levels were significantly lower than the other groups.

In conclusion, the study results were observed that the addition of alfalfa and enzyme to laying hens diets did not cause a significant change in performance and egg quality parameters. However, it can be said that the addition of alfalfa meal at least $8 \%$ without adding enzyme to the diet causes an increase in egg yolk color.
\end{abstract}

\section{Introduction}

Alfalfa meal is rich in protein but has high cellulose concentrations. Alfalfa is well balanced in amino acids and is a rich source of vitamins as well as minerals. Dehydrated alfalfa meal is often used at very low levels in poultry diets, due to its high crude cellulose and low metabolic energy content, but it is a rich source of vitamins and carotenoids. Enzymes are added to improve the ability of birds to digest fibers, increase energy use, and overcome the negative effects of fibers on intestinal lumen activity and fecal consistency (Leeson and Summers, 2008). In particular, the use of enzymes to eliminate the negative effects of cellulose, which restricts the use of high amounts of alfalfa meal, is believed to contribute positively. In addition, betaglucanase and arabinoxylanase can be added to alfalfacontaining diets to increase the performance and energy use of poultry (Mourao et al. 2006). When exogenous enzymes are supplemented, it may be possible to use alfalfa meal at moderate levels in poultry diets.
Anhydrous alfalfa meal is high in xanthophylls and is generally used at very low levels in poultry feeding to increase the degree of pigmentation of egg yolk (Fetcher and Papa, 1985).

Recent studies (Güçlü et al., 2004) reported that the addition of alfalfa meal up to $9 \%$ had no negative effect on body weight, egg production, feed intake and feed efficiency in quail. Mourao et al. (2006) reported that alfalfa meal supplementation in diet reduces the intake, egg weight, egg production and egg mass in laying hens. Laudadio et al. (2014) reported that the partial substitution of soybean meal with low-fiber alfalfa meal had no adverse effect on the growth performance of laying hens. In addition, none of the egg production and egg quality characteristics examined were affected by dietary treatment except egg yolk color. Egg yolk color was higher in chickens fed with low-fiber alfalfa meal diet. Heywang (1950) reported that the addition of alfalfa meal to egg diets at 5,10, 15 and 20\% levels did not affect feed intake, but that more than $5 \%$ of the drugs reduced egg production.

\footnotetext{
*Corresponding author email: ycufadar@selcuk.edu.tr
} 
The aim of the study was to evaluate the effect of the addition of alfalfa meal and enzyme on performance and egg quality characteristics of laying hens.

\section{Materials and Methods}

Twenty-four weeks-old, 144 Lohmann-LSL laying hens were randomly allocated to 8 experimental groups with 18 hens each, 6 replicates per group. Hens were fed on a basal diet, containing $16.5 \%$ crude protein and $2750 \mathrm{ME} \mathrm{Kcal} / \mathrm{kg}$ (Table 1). Basal diet was formulated to meet or exceed nutrient requirements of laying hens as recommended by the NRC (1994). The diets were consisted of 4 different levels of alfalfa meal $(0$, 4, 8 and $12 \%$ ) and 2 different levels (with/without) enzyme (Farmazyme 3000 PROENX). A total of 8 experimental diets consisting of 4 different dietary alfalfa and 2 different enzyme levels were tested in $2 \times 4$

Table 1

Composition of experimental diets

\begin{tabular}{|c|c|c|c|c|}
\hline \multirow{2}{*}{ Ingredients, $\%$} & \multicolumn{4}{|c|}{ Dietary alfalfa meal levels, $\%$} \\
\hline & 0 & 4 & 8 & 12 \\
\hline Corn & 52.0 & 50.0 & 46.5 & 45.6 \\
\hline Barley & 10.0 & 6.0 & 4.35 & 0.0 \\
\hline Soybean meal ( $43.8 \%$ crude protein) & 26.05 & 26.40 & 26.10 & 26.30 \\
\hline Alfalfa meal ${ }^{2}$ & 0 & 4 & 8 & 12 \\
\hline Vegetable oil & 0.40 & 2.15 & 3.80 & 5.40 \\
\hline Limestone & 9.10 & 9.00 & 8.80 & 8.70 \\
\hline Di-calcium phosphate & 1.70 & 1.70 & 1.70 & 1.65 \\
\hline Salt & 0.30 & 0.30 & 0.30 & 0.30 \\
\hline Premix & 0.25 & 0.25 & 0.25 & 0.25 \\
\hline DL-Methionine & 0.20 & 0.20 & 0.20 & 0.20 \\
\hline TOTAL & 1000 & 1000 & 1000 & 1000 \\
\hline \multicolumn{5}{|l|}{ Calculated nutrient (\% dry matter, DM) } \\
\hline Metabolizable energy, Kcal/kg & 2750 & 2753 & 2753 & 2750 \\
\hline Crude protein & 16.48 & 16.55 & 16.51 & 16.53 \\
\hline Calcium & 3.91 & 3.93 & 3.92 & 3.93 \\
\hline Available phosphorus & 0.41 & 0.42 & 0.42 & 0.42 \\
\hline L-Lysine & 0.88 & 0.88 & 0.88 & 0.89 \\
\hline DL-Methionine & 0.44 & 0.44 & 0.44 & 0.44 \\
\hline Methionine+cystine & 0.77 & 0.78 & 0.79 & 0.80 \\
\hline
\end{tabular}

${ }^{1}$ Premix provided the following per kg of diet: retinly acetate, $4.0 \mathrm{mg}$; cholecalciferol, $0.055 \mathrm{mg}$; DL- $\alpha$-tocopheryl acetate, $11 \mathrm{mg}$; nicotinic acid, 44 $\mathrm{mg}$; calcium-D-pantothenate, $8.8 \mathrm{mg}$; riboflavin sodium phosphate $5.8 \mathrm{mg}$; thiamine hydrochloride $2.8 \mathrm{mg}$; cyanocobalamin, $0.66 \mathrm{mg}$; folic acid, $1 \mathrm{mg}$; biotin, $0.11 \mathrm{mg}$; choline, $220 \mathrm{mg}$; Zn, $60 \mathrm{mg}$; Mn, $60 \mathrm{mg}$; Fe, $30 \mathrm{mg}$; Cu, $5 \mathrm{mg}$; I, $1.1 \mathrm{mg}$; Se, $0.1 \mathrm{mg}$.

${ }^{2}$ Alfalfa meal contains $13.2 \%$ crude protein, $28.1 \%$ crude cellulose.

The eggs were examined to determine the EW and eggshell quality characteristics (shell breaking strength, shell weight, and shell thickness) for collected eggs produced end of each period ( 28 days) for consecutive 2 days and sampled and analyses were done. Eggshell breaking strength was measured using a cantilever system by applying increasing pressure to - the broad pole of the shell using an Egg Force Reader (Orka Food Technology Ltd., Ramat Hasharon, Israel). The eggs were then broken, and eggshell, albumen, and yolk were separated and weighed. The egg yolk colour was determined using the Egg Analyzer (ORKA Food Technology Ltd, Ramat Hasharon, Israel) based on Roche Yolk Colour Fan and Minolta CR-400 colorimeter (Konica Minolta, Japan). factorial design for 12 weeks. The hens were housed in an environmentally controlled room equipped with 48 metal battery cages. Hens were kept in cages $(50 \mathrm{~cm}$ length, $50 \mathrm{~cm}$ width, $45 \mathrm{~cm}$ height) with 3 hens per cage. Feed and water were offered ad-libitum throughout the experiment. The lighting program was provided 16h lighting: $8 \mathrm{~h}$ darkness in a day throughout the experimental period.

The body weight of hens was determined by weighing the hens individually at the beginning and end of the experiment. Egg production (EP) was recorded daily. Feed intake (FI) was calculated as the mean for the subgroup for the 12-week trial period ( $\mathrm{FI}=$ given total feed - remaining feed in manger). Egg mass (EM) was calculated from the EP and egg weight (EW) data using the formula: $\mathrm{EM}=(\mathrm{EP} \% \times \mathrm{EW}) /$ Period (days). The feed conversion ratio (FCR) was calculated using the formula; FCR = FI/EM. 


\section{Results and Discussion}

The performance parameters are presented in Table 2. Dietary alfalfa and enzyme levels as a main factor, and their interactions had no significant effects on egg production, feed intake, feed conversion ratio, egg weight and egg mass among the treatment groups ( $\mathrm{P}>0.05$ ).

The findings of present study in terms of performance parameters were consistent with the results of Khajali et al. (2007) who reported that the inclusion of alfalfa meal had no significant effect on egg production, egg weight, egg mass, feed conversion ratio. Laudadio et al. (2004) reported that the group containing $15 \%$ alfalfa meal to diet had no significant effect on feed intake and feed efficiency compared with the control diet. Yuxin et al. (2004) showed that supplementation of alfalfa meal to laying hens diet had no significant effect on feed intake, egg weight and feed

Table 2

Effect of enzyme addition to diets containing different levels of alfalfa meal on performance of laying hens

\begin{tabular}{|c|c|c|c|c|c|}
\hline Treatments & $\begin{array}{l}\text { Egg produc- } \\
\text { tion, } \%\end{array}$ & $\begin{array}{l}\text { Feed intake, } \\
\mathrm{g} / \mathrm{d} / \mathrm{hen}\end{array}$ & $\begin{array}{l}\text { Feed conversion ratio, } \\
\mathrm{g} \text { feed } / \mathrm{g} \text { egg }\end{array}$ & $\begin{array}{c}\text { Egg weight, } \\
\mathrm{g}\end{array}$ & $\begin{array}{l}\text { Egg mass, } \\
\text { g/d/hen }\end{array}$ \\
\hline \multicolumn{6}{|l|}{ Alfalfa meal (\%) } \\
\hline ALM-0 & 97.49 & 106.4 & 1.84 & 59.50 & 58.02 \\
\hline ALM-4 & 96.64 & 105.0 & 1.82 & 59.85 & 57.85 \\
\hline ALM-8 & 96.92 & 105.3 & 1.83 & 59.51 & 57.68 \\
\hline ALM-12 & 96.99 & 105.9 & 1.82 & 60.17 & 58.38 \\
\hline Pooled SEM & 0.536 & 0.666 & 0.025 & 0.674 & 0.775 \\
\hline \multicolumn{6}{|l|}{ Enzyme $(\mathrm{g} / \mathrm{kg})$} \\
\hline 0 & 96.70 & 105.6 & 1.85 & 59.36 & 57.41 \\
\hline 1000 & 97.32 & 105.7 & 1.79 & 61.04 & 58.55 \\
\hline Pooled SEM & 0.379 & 0.471 & 0.018 & 0.476 & 0.548 \\
\hline \multicolumn{6}{|l|}{ Alfalfa*Enzyme } \\
\hline ALM- $0 * 0$ & 97.49 & 107.1 & 1.84 & 59.87 & 58.38 \\
\hline ALM-0*1000 & 97.49 & 105.6 & 1.84 & 59.13 & 57.66 \\
\hline ALM-4*0 & 95.32 & 104.4 & 1.87 & 58.95 & 56.19 \\
\hline ALM- $4 * 1000$ & 97.95 & 105.7 & 1.78 & 60.74 & 59.51 \\
\hline ALM- $8 * 0$ & 96.89 & 104.6 & 1.82 & 59.31 & 57.48 \\
\hline ALM-8*1000 & 96.96 & 106.0 & 1.84 & 59.72 & 57.88 \\
\hline ALM- $12 * 0$ & 97.09 & 106.2 & 1.85 & 59.31 & 57.60 \\
\hline ALM-12*1000 & 96.89 & 105.6 & 1.79 & 61.04 & 59.16 \\
\hline Pooled SEM & 0.758 & 0.942 & 0.035 & 0.952 & 1.100 \\
\hline
\end{tabular}

The eggshell quality parameters are presented in Table 3. Dietary alfalfa levels and enzyme addition, and their interactions had no significant effects on eggshell weight and eggshell breaking strength $(\mathrm{P}>$ 0.05). Eggshell thickness was significantly affected by the dietary enzyme addition $(\mathrm{P}<0.05)$, but it was not affected by dietary alfalfa and interactions of groups.

Similar results have been reported in previous studies. Khajali et al. (2007) found that the inclusion of alfalfa in the laying hen diet had no significant effects on eggs shell thickness and shell breaking strength. In another study, the use of alfalfa meal in laying hens diets have determined that there is a significant level effect on the relative eggshell weight. However, egg- conversion ratio compared to untreated meals. As a result, they reported that diets containing $5 \%$ alfalfa meal are most suitable according to production performance in laying hens. Al-Shami et al. (2011), the addition of rations alfalfa and enzyme in laying hens, feed consumption, feed conversion rate, egg weight and egg production did not cause a significant difference. Olgun and Y1ldiz (2015) reported that the different dietary levels of alfalfa meal had no significant effect on body weight change, egg production, egg weight, egg mass, feed conversion ratio in quails. However, Maurao et al. (2006) demonstrated that egg production, egg mass and feed intake were significantly reduced by inclusion of alfalfa to laying hen diets at level of $15 \%$ and addition of beta-glucanase and xylanase could not overcome the situation. Halaj et al. (1998) showed that the addition of alfalfa meal to diet of laying hens rations had a positive effect on egg weight and egg mass. Feed consumption was higher in experimental groups, but had no effect on egg production. 
fa meal had no significant effect on egg shell breaking strength in quails. Some research results, which are partly inconsistent with the current results, that Mourao et al. (2006) and Khajali et al. (2007) who reported that addition of alfalfa meal and enzyme to laying hens diets had no effect on eggshell thickness.

Table 3

Effect of enzyme addition to diets containing different levels of alfalfa meal on egg quality parameters of laying hens

\begin{tabular}{|c|c|c|c|}
\hline Treatments & $\begin{array}{c}\text { Eggshell weight, } \\
\text { g }\end{array}$ & $\begin{array}{c}\text { Eggshell thickness, } \\
\mathrm{mm}\end{array}$ & $\begin{array}{c}\text { Eggshell breaking strength, } \\
\mathrm{kg}\end{array}$ \\
\hline \multicolumn{4}{|l|}{ Alfalfa meal (\%) } \\
\hline ALM-0 & 5.87 & 0.395 & 4.68 \\
\hline ALM-4 & 5.92 & 0.393 & 4.54 \\
\hline ALM-8 & 5.98 & 0.399 & 4.85 \\
\hline ALM-12 & 5.97 & 0.398 & 4.77 \\
\hline Pooled SEM & 0.077 & 0.0023 & 0.087 \\
\hline \multicolumn{4}{|l|}{ Enzyme $(\mathrm{g} / \mathrm{kg})$} \\
\hline 0 & 5.89 & $0.394^{\mathrm{b}}$ & 4.69 \\
\hline 1000 & 5.98 & $0.399^{\mathrm{a}}$ & 4.79 \\
\hline Pooled SEM & 0.541 & 0.0017 & 0.062 \\
\hline \multicolumn{4}{|l|}{ Alfalfa*Enzyme } \\
\hline ALM-0*0 & 5.86 & 0.392 & 4.60 \\
\hline ALM-0*1000 & 5.88 & 0.398 & 4.76 \\
\hline ALM-4*0 & 5.75 & 0.386 & 4.44 \\
\hline ALM-4*1000 & 6.09 & 0.400 & 4.64 \\
\hline ALM-8*0 & 5.99 & 0.398 & 4.97 \\
\hline ALM- $8 * 1000$ & 5.97 & 0.401 & 4.72 \\
\hline ALM- $12 * 0$ & 5.94 & 0.399 & 4.75 \\
\hline ALM-12*1000 & 5.99 & 0.397 & 4.79 \\
\hline Pooled SEM & 0.108 & 0.0033 & 0.123 \\
\hline
\end{tabular}

The parameters of egg yolk color are presented in Table 4 . In the egg yolk color parameters, the $\mathrm{L}^{*}$ value was significantly affected by dietary alfalfa meal levels $(\mathrm{P}<0.01)$, and the groups fed with alfalfa meal containing diets at 8 and $12 \%$ levels were significantly lower than the others $(0$ and $4 \%)$. The $\mathrm{a}^{*}$ and roche values were significantly and similarly affected by the interactions $(\mathrm{P}<0.05)$, and the groups fed with alfalfa meal (with or without enzyme) diets at 8 and $12 \%$ levels were significantly lower than the others. The $b^{*}$ value was not affected by any of the treatments. The effect of enzyme addition to diet on all egg yolk color parameters were insignificant.

According to the results of the present study, in general, an increase in egg yolk color density was observed with the use of alfalfa meal to the diet. Khajali et al. (2007) found that laying hens fed with diets con- taining alfalfa meal tended to produce eggs with higher score of yolk pigmentation assessed by egg yolk color fan. In this study, enzyme supplementation had no impact on egg yolk color. It is known that alfalfa meal causes an increase in egg yolk pigmentation due to its high xanthophyll content (Laudadio et al., 2004). Yuxin et al. (2004) reported that the alfalfa meal increased, egg yolk color increased and was significantly higher than those who did not add alfalfa flour. It recommends the addition of 5\% alfalfa flour to be optimal. Halaj et al. (1998) found that egg yolk colour scores revealed significant differences among all treatments with the increase of yolk colour as the level of alfalfa increases. Al-Shami et al. (2011) reported similar results. In this study, it was observed that the egg yolk color improved by increasing the alfalfa meal level in the diets that the containing the enzyme of laying hens.

Table 4

Effect of enzyme addition to diets containing different levels of alfalfa meal on egg yolk color parameters of laying hens

\begin{tabular}{|c|c|c|c|c|}
\hline Treatments & $\mathrm{L}^{*}$, Lightness & $\mathrm{a}^{*}$, Redness & $\mathrm{b}^{*}$, Yellowness & Roche Color Score \\
\hline \multicolumn{5}{|l|}{ Alfalfa meal (\%) } \\
\hline ALM-0 & $62.69^{\mathrm{A}}$ & 4.35 & 49.65 & 7.24 \\
\hline ALM-4 & $61.74^{\mathrm{A}}$ & 4.90 & 48.84 & 7.93 \\
\hline ALM-8 & $59.99^{\mathrm{B}}$ & 7.22 & 48.62 & 9.07 \\
\hline ALM-12 & $59.99^{\mathrm{B}}$ & 7.32 & 48.44 & 9.14 \\
\hline Pooled SEM & 0.296 & 0.162 & 0.524 & 0.117 \\
\hline
\end{tabular}


Najm and Cufadar / Selcuk J Agr Food Sci, (2020) 34 (1), 14-18

Table 4(Continuation)

Effect of enzyme addition to diets containing different levels of alfalfa meal on egg yolk color parameters of laying hens

\begin{tabular}{lllll}
\hline Enzyme $(\mathrm{g} / \mathrm{kg})$ & & & & \\
\hline 0 & 61.37 & 5.69 & 49.32 & 8.27 \\
1000 & 60.84 & 6.21 & 48.46 & 8.42 \\
\hline Pooled SEM & 0.210 & 0.114 & 0.371 & 0.083 \\
\hline Alfalfa $*$ Enzyme & & & & \\
\hline ALM-0*0 & 62.72 & $4.35^{\mathrm{c}}$ & 49.50 & $7.36^{\mathrm{c}}$ \\
ALM-0*1000 & 62.66 & $4.36^{\mathrm{c}}$ & 49.81 & $7.11^{\mathrm{c}}$ \\
ALM-4*0 & 62.02 & $4.23^{\mathrm{c}}$ & 49.08 & $7.56^{\mathrm{c}}$ \\
ALM-4*1000 & 61.43 & $5.56^{\mathrm{b}}$ & 48.60 & $8.31^{\mathrm{b}}$ \\
ALM-8*0 & 60.21 & $7.22^{\mathrm{a}}$ & 49.42 & $9.14^{\mathrm{a}}$ \\
ALM-8*1000 & 59.78 & $7.23^{\mathrm{a}}$ & 47.81 & $9.00^{\mathrm{a}}$ \\
ALM-12*0 & 60.49 & $6.97^{\mathrm{a}}$ & 49.26 & $9.03^{\mathrm{a}}$ \\
ALM-12*1000 & 59.50 & $7.67^{\mathrm{a}}$ & 47.62 & $9.25^{\mathrm{a}}$ \\
\hline Pooled SEM & 0.419 & 0.228 & 0.741 & 0.166 \\
\hline
\end{tabular}

A, B: Within a column, values not sharing a common superscript are statistically different; $\mathrm{P}<0.01$

a, b, c: Within a column, values not sharing a common superscript are statistically different; $\mathrm{P}<0.05$

In conclusion, according to the results of this study, it was observed that the addition of alfalfa meal and enzyme to the laying hens diets did not cause a significant change in performance and egg quality parameters. Addition of alfalfa meal to the diet at $8 \%$ level caused an increase in egg yolk color without adding enzyme to the diet. However, the addition of enzyme to diets containing $4 \%$ alfalfa meal had an effect on egg yolk color increase.

\section{Acknowledgement}

This study is summarized from Elias KHUDHUR NAJM NAJM's master thesis and supported by the Selcuk University Scientific Research Projects Coordination, Project Number:19201037.

\section{References}

Al-Shami MA, Salih ME, Abbas TE (2011). Effects of dietary inclusion of alfalfa (Medicago sativa L.) leaf meal and Xylan enzyme on laying hens' performance and egg quality. Res. Opin. Anim. Vet. Sci. 2:14-18.

Fletcher D, Papa CM (1985). Utilization and yolk colouring capability of dietary xanthophylls from yellow corn, corn gluten meal, alfalfa and coastal Bermuda grass. Poultry Science, 64: 1458-1463.

Halaj M, Halaj P, Najduch L, Arpasova H (1998). Effect of alfalfa meal contained in hen feeding diet on egg yolk pigmentation. Acta Fytotechnica et Zootechnica (Slovak Republic).

Heywang BW (1950) High levels of alfalfa meal in diets for chickens. Poultry Science, 29: $804-811$.

Guclu BK, Işcan KM, Uyanik F, Eren M, Ağca AC (2004). Effect of alfalfa meal in diets of laying quails on performance, egg quality and some serum parameters. Arch. Anim. Nutr. 58:255-263.

Khajali F, Eshraghi M, Zamani F, Fathi E (2007). Supplementation of exogenous enzymes to laying hen diets containing alfalfa: Influence upon performance and egg yolk cholesterol and pigmentation. Proceeding $16^{\text {th }}$ European Symposium on Poultry Nutrition, France

Laudadio V, Ceci E, Lastella NMB, Introna M, Tufarelli V (2014). Low-fiber alfalfa (Medicago sativa L.) meal in the laying hen diet: Effects on productive traits and egg quality. Poultry Science, 93: 1868-1874.

Leeson S, Summers JD (2008). Commercial Poultry Nutrition. 3rd (ed.) Nottingham University Press, England. Pp: 67.

Minitab (2000). Minitab reference manual (release 13.0). Minitab Inc. State Coll., PA.

Mourao JL, Ponte PIP, Prates JAM, Centeno MSJ, Ferreira LMA, Soares MAC, Fontesm CMGA (2006). Use of $\beta$-glucanases and $\beta-1,4$-xylanases to supplement diets containing alfalfa and rye for laying hens: Effects on bird performance and egg quality. J. Appl. Poult. Res., 15:256-265.

NRC (1994). Nutrient Requirements for Poultry. 9th rev. ed. Natl. Acad. Press, Washington, DC.

Olgun O, Yıldiz AÖ (2015). Effect of Dietary Alfalfa Meal on Performance, Egg Quality, Egg Yolk Cholesterol and Hatchability Parameters of Quail Breeders. Turkish Journal of Agriculture-Food Science and Technology, 3(3): 103-106.

Yuxin Y, Chengzhang W, Hongxia L, Chunmei Z, Xifeng $H$ (2004). Effect of alfalfa Meal on Pe rformance, Egg Quality and Egg Yolk Color of Layers. Journal of Huazhong Agricultural, 3: 8(Abstract). 